"Stand A" for monocular microscopes and "Stand U" capable of taking various forms of binocular with either single or double objectives ; Reichert of Vienna exhibited microscopes, microtomes, projection and photographic apparatus ; Zeiss of Jena had a particularly interesting show of projection apparatus; A. C. Zambelli of Turin showed thermostats for embryological research and microscope observation in vivo. Allusion may here be made to the cinema film of young orang-utans shown by Prof. G. Brandes of Dresden, and the remarkable results displayed by Prof. Storch of Graz in his cinema studies of small crustacea under the microscope. In the Library of the University, Profs. Ageno and Ducceschi had arranged an exhibit of old books relating to biological science; an excellent illustrated catalogue was provided.

At the concluding session of the Congress reports were presented from the Commissions on Parasitology and on Nomenclature. It was decided that in future the Congress should be held at intervals of five years. In view of the large number of such meetings, the decision is probably wise, but it is to be hoped that care will be taken not to clash with other congresses in allied sciences. The International Institute of Intellectual Co-operation might be asked to act as a co-ordinating body. These congresses would be more useful if papers dealing with relatively special and trivial points were eliminated, especially when the results have already been published. Attention should be concentrated on general problems, towards the discussion of which authorities in various branches might contribute; and on such forms of co-operation as biological surveys, studies of migration, and especially action requiring government assistance. At present the Commission on Nomenclature seems to be the body that continually does really practical international work, however restricted its field may be. What the Permanent Committee of the Congress does between whiles, not even its members seem to know.

The preceding remarks are not intended to reflect in any way on the organisation of the Padua Congress, for which high praise is due to the energy of Prof. Enriques and the labours of the general secretary, Dr. Fausta Bertolini, with her lively and courteous staff of students of both sexes. Padua preserves the intimate and homely character of an ancient university city, and all its inhabitants united in so warm a welcome that the chief characteristic of the Congress now past was its friendly and homely character; and that, after all, is the chief value of these international gatherings.

\title{
The Liverpool and Manchester Railway Centenary Celebrations.
}

$\mathrm{T}$

HE Centenary Celebrations of the opening of the Liverpool and Manchester Railway were opened on Sept. 13 in St. George's Hall, Liverpool, by the American Ambassador, General Dawes, and were brought to a conclusion on Sept. 20 by a final performance of the great Pageant of Transport which had been shown night by night in Wavertree Playground.

Enacted on a stage 300 feet long and by some 3500 performers, the Pageant of Transport was designed to show the various methods of transport by animals, sledges, carts, wagons and coaches, and by the early railways. The final scene recalled the events of Sept. 15, 1830, when the Duke of Wellington, Sir Robert Peel, Mr. Huskisson, and other notable persons set out in the first of a procession of eight trains from Liverpool to Manchester. A replica of the original train had been constructed, and it was drawn by a replica of the engine Northumbrian which in 1830 was driven by George Stephenson himself. In the Wavertree Playground-a large open space kept solely for games-was also an exhibition of old and modern locomotives, together with examples of up-to-date carriages and wagons. It need scarcely be said that a copy of the Rocket was to be seen, while the Lion, an engine built for the Liverpool and Manchester Railway in 1838 , but now the property of the Liverpool Engineering Society, was under steam and worked "a train of 1830 " carrying passengers around a circular track.

While the pageant and exhibition and the shows at Wavertree provided for the popular taste, an exhibition of historic material, models, etc., in St. George's Hall provided food for the student and specialist and fascination for boys and girls. The celebrations have been held under the auspices of the corporations of Liverpool and Manchester and with the support of the London, Midland and Scottish Railway. The responsibility for the exhibition in St. George's Hall lay with a committee of which Mr. Robert Gladstone was chairman, and its success was largely due to his energy and foresight. While there were scores of model locomotives and a splendid model railway to be seen, the chief features of interest consisted of a series of exhibits illustrating the work of the pioneers, Cugnot, Trevithick, Murray, Blenkinsop, Hedley, Hackworth, Stephenson, and others, and another series relating particularly to the history of the Liverpool and Manchester Railway, much of the material for which came from the Liverpool Public Library.

There was much to recall the famous locomotive trials at Rainhill in 1829, between the Rocket, Sans Pareil, Novelty, and Perseverance, and one of the original cylinders of the Novelty, recently procured from an old works near Rainhill Station, was on view. The fellow cylinder for many years has been in the Science Museum. Of especial interest to serious students of railway history was the exhibition of a recently discovered letter from Robert Daglish referring to locomotive engines he made in 1812 and 1816 . Hitherto nothing has been known of these Lancashire engines, and inquiries at the colliery at which they worked have already brought some interesting facts to light.

A Handbook and Programme of the Centenary Celebrations was available, as were also a catalogue of the exhibition and a bibliography of the printed and illustrated material on the Liverpool and Manchester Railway in the Liverpool Reference Library. The London, Midland and Scottish Railway issued "One Hundred Years of Railways", written by Mr. Dendy Marshall; while Prof. G. S. Veitch's book, "The Struggle for the Liverpool and Manchester Railway", was published just before the celebrations.

Of other events connected with the celebrations mention may be made of the commemoration service in the Cathedral, the unveiling of a memorial tablet on the first railway station in Manchester, the performance of a pageant of the industries of Liverpool by the workers of the railway, and the public lectures in Picton Hall arranged by the Liverpool Corporation. At least two additions will be made to the nation's historic machines as a result of the celebration, as the cylinder of the Novelty is to be placed on permanent exhibition in Rainhill Station, and the locomotive Lion is to be placed on a pedestal in Lime Street Station, Liverpool. 